\title{
Retiform Sertoli-Leydig Cell Tumor of the Ovary
}

\author{
Gyu-Bong Yu' ${ }^{1}$, Seung-Kyu Choi ${ }^{2}$, Yun-Dan Kang ${ }^{1}$, Choong-Hak Park ${ }^{1}$ \\ ${ }^{1}$ Department of Obstetrics and Gynecology, College of Medicine, Dankook University, Cheonan, Korea \\ ${ }^{2}$ Department of Pathology, College of Medicine, Dankook University, Cheonan, South Korea \\ Email:pch10@dankook.ac.kr
}

How to cite this paper: Yu, G.-B., Choi, S.-K., Kang, Y.-D. and Park, C.-H. (2016) Retiform Sertoli-Leydig Cell Tumor of the Ovary. International Journal of Clinical Medicine, 7, 592-597.

http://dx.doi.org/10.4236/ijcm.2016.79065

Received: August 10, 2016

Accepted: September 10, 2016

Published: September 13, 2016

Copyright $\odot 2016$ by authors and Scientific Research Publishing Inc. This work is licensed under the Creative Commons Attribution International License (CC BY 4.0).

http://creativecommons.org/licenses/by/4.0/

\begin{abstract}
Sertoli-Leydig cell tumor of the ovary is a kind of sex cord-stromal tumor, which occurs between teens and twenties with symptoms including abdominal pain and swelling. The incidence rate is infinitely rare comprising less than $0.5 \%$ of all ovarian tumor. The average age of "retiform Sertoli-Leydig cell tumor" is 17 years as compared to 25 years for Sertoli-Leydig cell tumors as a group. We have experienced this rare case of retiform Sertoli-Leydig cell tumor in a 25-year-old foreign patient with the complaint of palpable mass on the right lower quadrant and an irregular menstrual period. The patient underwent right salpingo-oophorectomy and tumor stage was FIGO stage 1A. We report with a brief review of literature.
\end{abstract}

\section{Keywords}

Sertoli-Leydig Cell Tumor, Retiform Pattern, Sex Cord-Stromal Tumor, Ovary

\section{Introduction}

Sertoli-Leydig cell tumor is a very rare tumor originating from sex cord-stromal tumor. The incidence rate is infinitely rare comprising less than $0.5 \%$ of all ovarian tumor [1]. In 1905, Pick had found a microscopically odd ovary, which was comparable with male genital duct [2]. Meyer found that an odd ovary was extremely analogous to ductli efferents and defined it as Sertoli-Leydig cell tumor [3]. Among these Sertoli-Leydig cell tumors, Kanter and Klawans have first sorted out and reported retiform pattern in 1940 [4]. Sertoli-Leydig cell tumor is highly related with normal testis embryologically. World Health Organization (WHO) uses the terminology of the Sertoli-Leydig cell tumor as synonym of Androblastoma [5]-[7]. Whatever terms, Sertoli-Leydig cell tumor is considered as a clinically malignant tumor. And this tumor is usually occurred in young age female. The average age of 'retiform Sertoli-Leydig cell tumor' is 17 years as compared to 25 years for Sertoli-Leydig cell tumors as a group [8]-[11]. 
Young and Scully and WHO had classified the Sertoli-Leydig cell tumor into six patterns: 1) Well differentiated; 2) intermediate differentiation; 3) poorly differentiated; 4) retiform; 5) heterologous elements; and 6) mixed. A typical microscopic feature of the retiform pattern shows irregular anastomosing tubules made by cuboidal or columnar cells [7] [9] [12].The objective of our paper is to present this rare case of retiform Sertoli-Leydig cell tumor in a 25 -year-old woman and review of relevant literatures.

\section{Case Report}

A 25-year-old woman visited a local Obstetrics and Gynecology clinic because of amenorrhea for six months and right lower quadrant pain occasionally. Computed tomography (CT) scan revealed a tumor of the right ovary, measuring $5 \mathrm{~cm}$ in diameter. After then she was referred to the Department of Obstetrics and Gynecology in Dankook University Medical Center for further management.

There was no evidence of hirsutism, baldness, or deepening of the voice. On physical examination, a boggy feeling mass was palpated with tenderness on the right lower quadrant. Cervix showed normal appearance and no motion tenderness. Complete blood count, blood coagulation test, liver function test, renal function test, electrolyte, lipid test, urine test, chest X-ray, and electrocardiography were all within normal ranges. Papanicolaou smear test showed atrophy with inflammation. Serum levels of $\alpha$-FP was $4.4 \mathrm{ng} / \mathrm{mL}, \mathrm{CA}-125$ was $23.9 \mathrm{U} / \mathrm{mL}$, and SCC was $0.84 \mathrm{ng} / \mathrm{mL}$.

Transvaginal ultrasonography showed an approximately $6.1 \times 4.8 \mathrm{~cm}$ sized multilocular mass including the solid portion on the right ovary. There were no abnormal findings on the uterus. Magnetic resonance image (MRI) revealed the suspected diagnosis of cystadenofibroma or sex cord-stromal tumor originating from the right ovary (Figure 1).

Pelviscopic operation was performed. Diagnostic pelviscopy showed a large mass originating from the right ovary and no adhesion in the pelvic cavity. Right salpingo-oophorectomy was performed. Specimen and abdominal fluid for cytology were sent to the pathology. Pathologic classification was read according to the International histologic classification of tumors modified by Roth, et al. Grossly, the tumor was yellow tan solid mass with partly cystic area, measuring $6 \times 5 \times 3 \mathrm{~cm}$. Microscopically, the tumor showed solid cords, slit-like tubules, and irregularly branching cystic spaces with some papillae lined by cuboidal cells with round to ovoid nuclei (Figure 2). Tumor cells showed no significant nuclear atypia, and mitotic figures were rare. Immunohistochemical staining results were positive for inhibin but negative for vimentin, Wilm's tumor protein (WT-1) and p53. Cytology in abdominal fluid revealed no tumor cell. According to this histologic finding and immunohistochemical staining results, the tumor was found to be Sertoli-Leydig cell tumor with retiform pattern.

The patient was discharged on the 4th post-operative day without any other complication. On the 9th post-operative day, she was re-admitted for staging work-up of ovarian cancer. Tumor markers and hormone tests were performed (LH $14.24 \mathrm{mIU} / \mathrm{mL}$, FSH $4.18 \mathrm{mIU} / \mathrm{mL}$, estradiol $52.5 \mathrm{pg} / \mathrm{mL}$, testosterone $0.50 \mathrm{ng} / \mathrm{mL}$, progesterone 

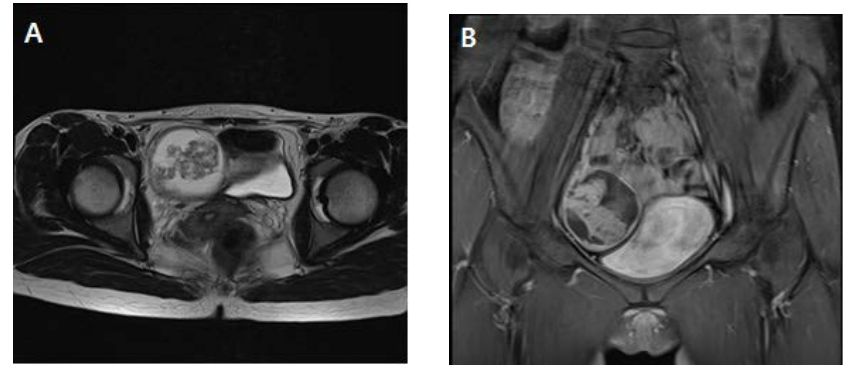

Figure 1. Pelvis Magnetic Resonance Imaging image shows a large multi-cystic mass measuring approximately $5.8 \times 5.5 \times 5.5$ $\mathrm{cm}$ in size, with an enhancing irregular thick wall and an amorphous enhancing solid portion with low signal intensity in the right pelvic cavity. (A) Coronal view and (B) axial view.
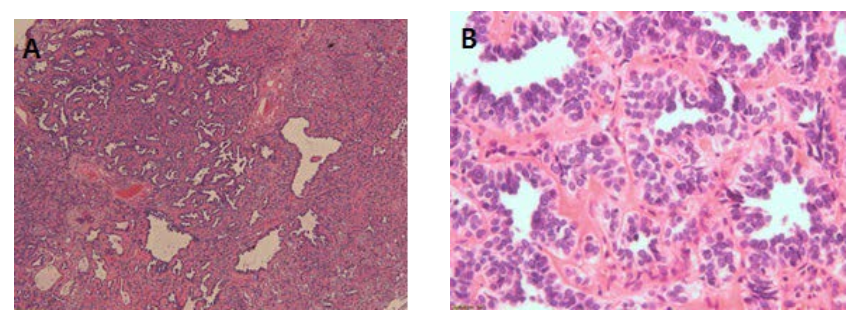

Figure 2. Microscopic finding of the Retiform Sertoli-Leydig cell tumor. The tumor showed irregular network of slit-like tubules and elongated spaces, typifying retiform Sertoli-Leydig cell tumor (A; H\&E stain, $\times 40)$. The tubules are lined by Sertoli cells with round to ovoid nuclei that exhibit varying degrees of stratification (B; H\&E stain, $\times 400)$.

$0.45 \mathrm{ng} / \mathrm{mL}, 5 \alpha$-dihydrotestosterone $0.11 \mathrm{ng} / \mathrm{mL}$, prolactin $3.66 \mathrm{ng} / \mathrm{mL}$, CA-125 28.2 $\mathrm{U} / \mathrm{mL}, \alpha$-FP $2.2 \mathrm{ng} / \mathrm{mL}$, CA19-9 25.6 U/mL, SCC $0.75 \mathrm{ng} / \mathrm{mL}$ ). All of them were within normal limit. MRI, positron emission tomography (PET)-CT, intravenous pyelography (IVP), cystoscopy, sigmoidofibroscopy, and colon studies showed no abnormal findings. Therefore we concluded that any other adjuvant management would not be necessary. She is followed up every 3 months, and shows no evidence of disease till now for 25 months after the surgical treatment. Follow-up MRI examination revealed no evidence of local recurrence or distant metastasis. And now she is happily pregnant state at 29 weeks of gestational age.

\section{Discussion}

Sertoli-Leydig cell tumor, papillary serous cystadenocarcinoma, malignant mixed müllerian tumor and yolk sac tumor cannot easily be distinguished and diagnosed. Sertoli-Leydig cell tumor should be differentiated from these tumors with some key points. Clinical features and average onset age of papillary serous cystadenocarcinoma and malignant mixed müllerian tumor differ from those of Sertoli-Leydig cell tumor. These tumors tend to occur in the older age group. Between yolk sac tumor and Sertoli-Leydig cell tumors, yolk sac tumor is more pathologically primitive and includes ab- 
undant glycogen. Also yolk sac tumor shows positive sign for $\alpha$-FP staining [11].

In 2002, Young and Scully classified Sertoli-Leydig cell tumor according to six subtypes and incidence rates were: well differentiated (11\%), intermediate differentiation (54\%), poorly differentiated (13\%), retiform pattern (15\%), heterologous elements, and mixed type. Virilization was observed in only $33 \%$ of Sertoli-Leydig cell tumor patients [9] [10] [12].

Retiform patterned Sertoli-Leydig cell tumor is only found to be intermediate differentiation and poorly differentiated type [4]. In general, retiform pattern occurs in the younger age group and with less virilization than other types [10]. When a patient visits hospital for the first time, the chief complaint is usually unilateral abdominal pain due to a huge abdominal mass. Young and Scully reported on 24 retiform pattern cases of unilateral mass in 25 patients. With visual inspection, the retiform pattern consisted of a solid or cystic portion with a yellowish liquid portion and measured $8 \mathrm{~cm}$ to $22 \mathrm{~cm}$, which was larger than other Sertoli-Leydig cell tumors [9] [13]. Some retiform Sertoli-Leydig cell tumor showing papillary pattern may mimic serous adenocarcinoma. In this case, as described above, the tumor showed no prominent cytologic atypia and negative WT-1 and p53 staining results. These findings were not consistent with serous adenocarcinoma. Futhermore, positive inhibin staining result indicated this case was retiform Sertoli-Leydig cell tumor rather than serous adenocarcinoma.

According to a report by Young and Scully, malignancy potential is $0 \%$ in the well differentiated, $11 \%$ in the intermediate differentiation, $59 \%$ in the poorly differentiated, and $19 \%$ in the heterologous elements type. Distance metastasis rate was $10 \%$ to $30 \%$ and recurrence rate was $66 \%$ after the first treatment trial. The prognosis was worse in cases where Sertoli-Leydig cell tumor recurred within one year from treatment [10] [11] [13].

The standard treatment for Sertoli-Leydig cell tumor is surgical treatment. Especially in early stage of Sertoli-Leydig cell tumor (FIGO stage 1A), standard treatment is unilateral salpingo-oophorectomy. In the elderly group or patients with advanced stage, debulking surgery could be attempted, however, there are controversies regarding the benefits and prognosis [14]. PEB (cisplatin, etoposide, and bleomycin) and PAC (cisplatin, dactinomycin, and cyclophosphamide) chemotherapy could be performed for intermediate differentiation or poorly differentiated type. But there is no evidence of preventing recurrence or increasing therapeutic efficacy [15].

For young patients, fertility may be affected by debulking surgery and chemotherapy. Some surgeons including Telerman reported that only unilateral salpingo-oophorectomy had shown a cure rate of $88.9 \%$ in FIGO stage 1A to Sertoli-Leydig cell tumor retiform pattern patients [13].

Both treatment and fertility preservation are the key points in management of Sertoli-Leydig cell tumor, especially for young women. In prudent consideration of FIGO stage $1 \mathrm{~A}$ and fertility preservation unilateral salpingo-oophorectomy was performed. The final pathologic diagnosis was Retiform Sertolig-Leydig cell tumor of intermediate differentiation type, which had less malignant potential than poorly differentiated type. 
And so post-operative adjuvant chemotherapy was not attempted. The patient has been in disease-free state for 25 months after the surgical treatment. And now she is happily pregnant state at 29 weeks of gestational age.

\section{Conclusion}

We presented the above rare case of retiform Sertoli-Leydig cell tumor in a 25-year-old foreign patient. The patient underwent right salpingo-oophorectomy and tumor stage was FIGO stage 1A. Sertoli-Leydig cell tumor shows a variety of subtypes. It occurs relatively at a young age and has a malignant potential. However, there are no standard treatment guidelines for patients who want to preserve fertility. Because of the low incidence of Sertoli-Leydig cell tumor, only a few small scale and large-scale long term studies have been conducted in light of fertility preservation and recurrence. Future large-scale studies including meta-analysis are necessary.

\section{Conflict of Interest}

No potential conflict of interest relevant of this article was reported.

\section{References}

[1] Roth, L.M., Anderson, M.C., Govan, A.D.T., Langley, F.A., Gowing, N.F. and Woodcock, A.S. (1981) Sertoli-Leydig Cell Tumors-A Clinicopathologic Study of 34 Cases. Cancer, 48, 187-197. http://dx.doi.org/10.1002/1097-0142(19810701)48:1<187::AID-CNCR2820480130>3.0.CO;2 $\underline{-1}$

[2] Pick, L. (1905) Ueber Neubildungen am Genitale bei Zwittern nebst Beutraegen zur von den Adenomen des Hodens und Elerstocks. Arch Genaekol, 76, 1912.

[3] Meyer, R. (1931) Pathology of Some Special Ovarian Tumors and Their Relation to Sex Characteristics. American Journal of Obstetrics \& Gynecology, 22, 679-713. http://dx.doi.org/10.1016/S0002-9378(31)90960-5

[4] Kanter, A.E. and Klawans, A.H. (1940) Arrhenoblastoma of the Ovary. American Journal of Cancer, 40, 474-484.

[5] Piver, S.M. (1983) Ovarian Malignancies. Current Reviews in Obstetrics and Gynecology. Churchill Livingstone, New York, 183.

[6] Russel, P. and Bannatyne, P. (1989) Androblastomas. In: Russell, P. and Bannatyne, P., Eds., Surgical Pathology of the Ovaries, Churchill Livingstone, Edinburgh, New York, 346-365

[7] Tavassoli, F.A. and Devilee, P., Eds. (2003) World Health Organization Classfication of Tumors. Pathology \& Genetics of Tumours of the Breast and Female Genital Organs. IARC (International Agency for Research on Cancer) Press, Lyon, 153-158.

[8] Roth, L.M., Slayton, R.E., Brady, L.W., Blessing, J.A. and Johnson, G. (1985) Retiform Differentiation in Ovarian Sertoli-Leydig Cell Tumors: A Clinicopathologic Study of Six Cases from a Gynecologic Oncology Group Study. Cancer, 55, 1093-1098. http://dx.doi.org/10.1002/1097-0142(19850301)55:5<1093::AID-CNCR2820550526>3.0.CO; $\underline{2-\mathrm{O}}$

[9] Young, R.H. and Scully, R.E. (1983) Ovarian Sertoli-Leydig Cell Tumors with Retiform Pattern: A Problem in Histopathologic Diagnosis. A Report of 25 Cases. American Journal 
of Surgical Pathology, 7, 755-771. http://dx.doi.org/10.1097/00000478-198307080-00005

[10] Young, R.H. and Scully, R.E. (1985) Ovarian Sertoli-Leydig Cell Tumors. A Clinico-Pathological Analysis of 207 Cases. American Journal of Surgical Pathology, 9, 543-569. http://dx.doi.org/10.1097/00000478-198508000-00001

[11] Mooney, E.E., Nogales, F.F., Bergeron, C. and Tavassoli, F.A. (2002) Retiform Sertoli-Leydig Cell Tumours: Clinical, Morphological and Immunohistochemical Findings. Histopathology, 41, 110-117. http://dx.doi.org/10.1046/j.1365-2559.2002.01426.x

[12] Young, R.H. and Scully, R.E. (2002) Sex Cord-Stromal, Steroid Cell and Other Ovarian Tumors. In: Blaustein, A. and Kurman, R.J., Eds., Blaustein's Pathology of Female Genital Tract, 5th Edition, Springer, New York, 929-939.

[13] Talerman, A. (1987) Ovarian Sertoli-Leydig Cell Tumor (Androblastoma) with Retiform Pattern. Cancer, 60, 3056-3064.

http://dx.doi.org/10.1002/1097-0142(19871215)60:12<3056::AID-CNCR2820601233>3.0.C $\underline{\mathrm{O} ; 2-\mathrm{R}}$

[14] Lou, W., Cao, D., Yang, J., Lina, G. and Shen, K. (2011) Retiform Sertoli-Leydig Cell Tumor of Ovary in a 9-Year-Old Girl: Case Report and Review of the Literature. International Journal of Clinical Oncology, 16, 705-708. http://dx.doi.org/10.1007/s10147-011-0186-6

[15] Gershenson, D.M., Morris, M., Burke, T.W., Levenback, C., Matthews, C.M. and Wharton, J.T. (1996) Treatment of Poor-Prognosis sex-Stromal Tumors of the Ovary with the Combination of Bleomycin, Etoposide, and Cisplatin. Obstetrics \& Gynecology, 87, 527-531. http://dx.doi.org/10.1016/0029-7844(95)00491-2

\section{Submit or recommend next manuscript to SCIRP and we will provide best service for you:}

Accepting pre-submission inquiries through Email, Facebook, LinkedIn, Twitter, etc. A wide selection of journals (inclusive of 9 subjects, more than 200 journals)

Providing 24-hour high-quality service

User-friendly online submission system

Fair and swift peer-review system

Efficient typesetting and proofreading procedure

Display of the result of downloads and visits, as well as the number of cited articles

Maximum dissemination of your research work

Submit your manuscript at: http://papersubmission.scirp.org/ 